Meta

Journal des traducteurs

Translators' Journal

\title{
Shaping Translation: A View from Terminology Research
}

\section{Bassey E. Antia, Gerhard Budin, Heribert Picht, Margaret Rogers, Klaus-Dirk Schmitz et Sue Ellen Wright}

Volume 50, numéro 4, décembre 2005

Pour une traductologie proactive - Actes

For a Proactive Translatology — Proceedings

Por una traductología proactiva - Actas

URI : https://id.erudit.org/iderudit/019907ar

DOI : https://doi.org/10.7202/019907ar

Aller au sommaire du numéro

Éditeur(s)

Les Presses de l'Université de Montréal

ISSN

0026-0452 (imprimé)

1492-1421 (numérique)

Découvrir la revue

Citer cet article

Antia, B. E., Budin, G., Picht, H., Rogers, M., Schmitz, K.-D. \& Wright, S. E. (2005).

Shaping Translation: A View from Terminology Research. Meta, 50(4).

https://doi.org/10.7202/019907ar

\section{Résumé de l'article}

Cet article aborde la terminologie dans l'optique de la traduction (profession, pratique, théorie) durant les cinquante dernières années - période correspondant à la vie de META. Après avoir esquissé ce que le profil contemporain du traducteur doit à la terminologie, l'article examine à tour de rôle: (a) les étapes dans la constitution de cette science des termes, (b) comment cette science a acquis droit de cité dans les programmes de formation des traducteurs, (c) le cadre explicatif contemporain qu'elle propose pour rendre compte des textes techniques et de leur traduction, (d) les retombées de ce cadre pour les secteurs des industries de la langue qui se justifient largement par rapport à la traduction. 


\title{
Shaping Translation: A View from Terminology Research
}

\author{
BASSEY E. ANTIA \\ University of Maiduguri, Maiduguri, Nigeria \\ bantia1@yahoo.co.uk \\ GERHARD BUDIN \\ University of Vienna, Vienna, Austria \\ HERIBERT PICHT \\ Copenhagen Business School, Copenhagen, Denmark \\ MARGARET ROGERS \\ University of Surrey, London, United Kingdom \\ KLAUS-DIRK SCHMITZ \\ University of Applied Sciences, Cologne, Germany \\ SUE ELLEN WRIGHT \\ Kent State University, Kent, United States
}

\begin{abstract}
RÉSUMÉ
Cet article aborde la terminologie dans l'optique de la traduction (profession, pratique, théorie) durant les cinquante dernières années - période correspondant à la vie de META. Après avoir esquissé ce que le profil contemporain du traducteur doit à la terminologie, l'article examine à tour de rôle: (a) les étapes dans la constitution de cette science des termes, (b) comment cette science a acquis droit de cité dans les programmes de formation des traducteurs, (c) le cadre explicatif contemporain qu'elle propose pour rendre compte des textes techniques et de leur traduction, (d) les retombées de ce cadre pour les secteurs des industries de la langue qui se justifient largement par rapport à la traduction.
\end{abstract}

\begin{abstract}
This article discusses translation-oriented terminology over a time frame that is more or less congruent with META's life span. Against the backdrop of the place of terminology in shaping professional issues in translation, we initially describe some stages in the process by which terminology has acquired institutional identity in translator training programmes and constituted its knowledge base. We then suggest a framework that seeks to show how theory construction in terminology has contributed to a better understanding of technical texts and their translation. A final section similarly illustrates how this overarching theoretical scheme has driven, or is at least consistent with, products and methods in the translation sector of the so-called language industries.
\end{abstract}

\section{MOTS-CLÉS/KEYWORDS}

translation-oriented terminology, theory construction, terminology theory, theory of indeterminacy, technical translation

\section{Terminology in Translation and Elsewhere: Identity and History of a Discipline}

Of all the professional groups interested in specialist communication, technical translators were perhaps the earliest to recognise the need for knowing and managing terminologies as an essential part of their task. But this awareness was largely intuitive, and therein lay for long the challenge of training. Training programmes are set up typically on the basis of some explicit and formalized 
knowledge, in order to cut down on the time length associated with a uniquely experiential or learning-by-doing approach to instruction. Correspondingly, until about the mid-seventies of the last century (and this date applies only to the most visionary of environments), much of whatever counted as terminology instruction was offered in the context of solving specific problems, and was therefore lacking in coherence as well as in depth. This situation explains some of the naïve views concerning the simplicity of technical translating (in contrast to, say, its literary counterpart) which we find even in the writings of the earliest theorists of terminology.

\subsection{Shaping Professionalism in Translation.}

The growth of theoretical knowledge made possible the introduction of distinct terminology courses in technical translation programmes, such as the one given by Wüster at the University Vienna, which the relevant literature speculates to have been one of the earliest. Advances in theoretical knowledge not only meant that earlier views on technical translation had to be recanted, but also that a basis had become available for defining the professional profile of terminologists. A survey in the 1990s (cf. Picht 1993) of known terminology curricula in translation programmes worldwide showed that even though emphases differed, programmes analyzed had a common core of modules: the interdisciplinary character of terminology, its basic concepts, relations obtaining between objectconcept, as well as between concept-term (polysemy, homonymy, synonymy, etc.), terminology management, information and documentation.

This formalized knowledge became the basis for developing the professional profile of the terminologist. (See for instance the most recent description of the professional profile of the terminologist published in 2004 by the Council for German Language Terminology, Rat für Deutschsprachige Terminologie, RaDT). Interestingly, this profile can be applied - mutatis mutandis - to technical translators too, in addition to being relevant to such other professionals as localizers, technical writers and so on. There hardly is a job advertisement in these areas that does not mention familiarity with principles of terminology management and familiarity with terminology management systems. Indeed many translation graduates regularly discover that it is their familiarity with terminology management and the underlying principles that lands them their first job.

\subsection{Terminology: Constitution of a Knowledge Base.}

Practice-oriented terminology activity and theoretical considerations sprang up in several critical venues: Western Europe, Eastern Europe (primarily the former Soviet Union), North America, with its strongest concentrated centre, both in theoretical and practical terms in French Canada, and in the so-called "developing countries", with their necessary preoccupation with language planning, the creation of culturally and linguistically adequate neologisms, as well as with technology and knowledge transfer. Indeed, worldwide trends mirror an initial pragmatic orientation directed toward the evolution of practice-oriented methodological guidelines in order to rapidly solve existing problems, initially in engineering, then later in other areas - all of this without any theoretical grounding.

Under the influence of the Wirtschaftslinguistik-movement (Picht 1998:336-341) and the Prague School of Linguistics as well as the works of Russian linguists on LSP and terminology (Lotte, Reformatsky, etc.), outlines of initial theoretical approaches appeared in Europe, and these would influence later developments there and elsewhere. Nevertheless, a coherent theory of terminology did not emerge in the first decades of the terminology movement; terminological activities were pragmatically oriented and marked by either a strong linguistic orientation (especially in language planning), or by a predominantly professional, non-linguistic approach. Indeed, Wüster and the early North Americans had more training as engineers and librarians than as formal linguists. They tended to look for their theory in Frege, Ogden \& Richards, and Peirce, but also in library science (Ranganathan, etc.). Although they were linguists in the sense that they were schooled in languages, they were not students of formal linguistics necessarily

A second phase started around 1970 and lasted approximately until 1990. The main characteristic of this period is a rapprochement between linguistics and terminology, facilitated by an increasing interest in, and an intensification of the research into, LSP, professional 
communication, text linguistics and pragmatics. This broadening of the scope of linguistics paved the way for a natural embedding of terminology (Laurén et al. 1998:349-353).

In a third phase starting approximately in 1990, we see a broad-based acceptance of terminology as a necessary component in the training of LSP translators. More significant for this phase is the interest in the elaboration of sound foundations of the theory of terminology on the one hand, and, on the other, the determination of the place of terminology as an independent discipline in reality, a basic question of the philosophy of science (e.g. Antia 2001:65-84; Budin 2001:7-23; Wright 2003:111-135). Admittedly, questions of philosophy of science in relation to terminology were broached even in the first phase (e.g. a seminar on this issue was held in Moscow in 1969); however, with the repeated claim by some researchers that terminology is not an independent science, philosophical questions continue to give rise in the third phase to heated, but not always fruitful, debates.

Another important factor which characterizes the third phase is the introduction into terminology research of insights from other sciences that had hitherto not been taken into consideration. Examples include cognitive psychology, cognitive linguistics, theories on the evolution of languages, knowledge ordering (e.g. ontologies), classification and representation and the ever-increasing host of electronic tools for terminology research and management.

\section{Fifty Years of Terminology Research as Construction of Indeterminacy}

Terminology is somewhat like the anecdotal elephant that gave rise to different tactile impressions. As new fields have emerged or older fields have innovated their working methods, it has become obvious that one can do terminology without being primarily interested in translation, or that translators, interpreters, indexers, language planners, subject specialists, standardizers of nuts and bolts and rail gauges, localizers, ontologists, artificial intelligence experts, discourse analysts, and so on, all have their tactile impressions of this elephant, and that these impressions are all legitimate.

This grandiosity and utilitarianism - at best incipient in the $1950 \mathrm{~s}$ - was bound to pose a problem for theory construction. Based on traditions of terminological standardization in science (associated with Lavoisier, de Morveau, etc.), and on their own work in technology, Wüster, Lotte and their associates began a process of theory construction, which meant disarticulating from etic to emic levels. Thus began, for instance, Wüster's writings on terminology, culminating in the early 1970 s in his posthumously published book attempting to construct an overarching theory. This effort at theoretical disarticulation or middle range theory construction has generated a debate that has, paradoxically, concerned itself with describing subsequent work as either Popperian hypothesis falsification or Kuhnian paradigm articulation. While Popper and Kuhn can be perfectly accommodated within the same mould, a number of our colleagues have been disingenuously Popperian in orientation, ostensibly to secure prominence in the historiography of terminology as reinventors of the wheel.

\subsection{Overview of Research Strands.}

Like atomic physics giving birth to subatomic physics, or translation studies in a Quineac era questioning the very possibility of translating, or theology scholars arguing over divinity, terminology theory has, thanks to the critical bent of both the Kuhnians and the Popperians, rapidly developed these past 50 years by demonstrating precisely the opposite of what might intuitively have been seen as its mandate: setting limits on terms! Perhaps this paradox is an indispensable phase of backward movement in all fields that sets the agenda for future action, or that properly focuses goals and strategies. Many workers in the field would probably characterize their work in this way, irrespective of the particular thrust: philosophy or knowledge theory, including diachronic/dynamic accounts of knowledge change and issues of epistemology; collocations as they affect term use or even formation; issues surrounding abstraction models of concept formation; diversity of interests and approaches in terminology; data entry models in terminology databases; the cultural underpinnings of term acceptation; text ecology; issues in term formation and the nature of terminological reference; non-static concepts; terminology within language planning environments; the transcendental or evocative function of terms; non-verbal forms of object and 
concept representation; sign models; non positivistic concept systems. See a comparable survey in Antia (2001).

\subsection{A Theory of Indeterminacy.}

With respect to translating, one hallmark of theoretical terminology research these past 50 years has been to draw attention to the pervasiveness of indeterminacy, a concept indexed by any or a combination of the following: unpredictability, indefiniteness, vagueness, inconsistency, uncertainty, instability, slipperiness, and so on. It is rather paradoxical that terminology, which, following Beaugrande, is a control mechanism for ensuring determinacy in specialized domains, has to itself be pushed to a lower and less deterministic status by the field for which it is research object. Obviously, while a measure of indeterminacy is indispensable for innovation and therefore of potential interest to buffs of a given discipline, it may have a nuisance value for translators who want to turn a fast buck or who have to work to pretty tight deadlines.

The indeterminacy project in theoretical terminology has underpinned research directed at the three corners (object, concept and symbol) of the traditional semiotic triangle. The conclusion would seem to be one of non-consubstantiality among the elements of the triad, and an extreme suspicion of, or an invitation to always verify, any constitutive dyads (object- concept; conceptsymbol; object-symbol). Notice that this is a radical departure from Ogden \& Richards for whom only the link in the object-name dyad was mediated. This suspicion of how each dyad is constituted or linked has always been very important, but is perhaps even more so today with intertextuality crossing genre lines and discourses becoming increasingly multi-generic. These new ways of meaning-making are at once suggestive of the almost endangered status of the traditional concept of 'register' and of a rise in polysemy in texts.

Research directed at the object has essentially been philosophically-oriented, dealing with ontological and epistemological positions for terminology. In the earliest attempts at theory formulation, the concept of a formal object was introduced to suggest that reality is not passively apprehended but mediated through a constellation of biases (cf. Felber \& Budin 1989). Thus, that which we call 'coal' is apprehended differently by geologists, miners, power economists, and so on. This relativity or ontological pluralism is consistent with the subsequent claim for terminology of mid-spectrum epistemological positions, namely critical realism (hypothesis of a real world which sometimes differs from the way it appears to us) and hypothetical realism (hypothesis of a real world with structures that are discoverable only to a certain extent) - cf. Budin (1994). This is no latter day rejection of neo-positivistic or radical constructivist positions that claim, respectively, that there is reality out there captured just as it is, and that the world is simply our mental creation of it. There can therefore be no certainty as to the reality-correlation of what we know.

From the standpoint of the concept, contribution to the indeterminacy project has come from several angles. Firstly, there has been a questioning and a refinement of abstraction, the dominant Aristotelian model of concept formation (Gerzymisch-Arbogast 1996, Picht 1997). In implying that a (general) concept represents common features of individual entities, whose differences are then trashed out or discarded, the abstraction model causes the question to be posed as to whether a real exemplar of this general concept exists, or whether any individual exists that is adequately described by this concept. In effect, is the mean THE message?

The answer, whether couched in the rhetoric of the debate between Aristotle's necessary and sufficient conditions and Wittgenstein's family resemblances, or of some other debate, has been an invitation to practise or recognise some form of analytical casuistry, which, in Hunter's clinical acceptation, is "the comparative analysis of a particular case with all its special circumstances in an effort to relate that case reliably" to "tested generalizations" (Hunter 1991).

Secondly, input to the indeterminacy project at the concept level has come from awareness that in complex systems (an instance of which communication is) allowance has to be made for perspectivism (Beaugrande), "perspectivization" (Rogers), views (in Artificial Intelligence), or multidimensionality (Bowker), i.e., the visualization of polyfaceted meaning within multidimensional conceptual space. On this argument, there can be several standpoints for apprehending a concept, and while these different standpoints are not necessarily contradictory they are able to develop such functional specializations as to raise, at the level of designation, debates on 
interlingual equivalence - pitting subject experts (who may operate with intuitive or holistic apprehension frames) and domain-knowledgeable translators (operating with analytical, what-doesit-mean-as-it-occurs-here-and-now frames). We see here a basis, intralingually, for quasi-synonyms and, interlingually, for ephemeral equivalents.

More extreme formulations of perspectivism indirectly question some of our ideas of what the concept is. In defining the concept, not as a unit of thought, but as an element of thinking, some researchers (Felber, Picht) invite a rethink on the putative stability of the concept. To say that the concept is an element of thinking is to associate it with a process, rather than with a product. Damasio fleshes out this point, as Wright (2003) recently notes. On the basis of neuroanatomy experiments, functional imaging and so on, Damasio describes memory as essentially reconstructive - the material for this process being images (facets or aspects) associated with a previously encountered object to which a name is given. On this analysis, a concept has as its basis a set of potential and fleeting images, which will converge in different configurations within different spatiotemporal windows.

The symbol has also had its place in the indeterminacy current. Fred Rigg's onomantic projects stemmed from the awareness that texts were not merely reality conditioned, but were also reality constitutive (cf. Riggs 1987). In playing this latter role, social science writing constantly packs new meanings into existing terms, rather than create new terms, thus contributing to problems of determinacy. By the same token, there is a parallel tendency to refuse to use the same term for a concept that someone else has used previously.

Although the goal of the onomantic projects was to encourage creation of new terms and to overcome the putative face threatening resonance of launching neology, some other thinking suggests that the inability to consistently use a term to denote a given concept may in fact have something quasi-anthropological to it, perhaps associated with the very nature of language and writing (Antia 2002). On this argument, it is in the nature of language to offer its users choices syntagmatically, paradigmatically, and so on. For instance, any word or term chosen to fill a paradigmatic slot in a construction will often be one of several available alternatives for the semantic relationships being constructed. Lemke (1990) makes the point that whereas the relationships (classification, e.g. X is a Y; causality, e.g. X causes Y, etc.) involving these terms will typically be stable, the specific terms themselves can be replaced by other terms. After all, a time-honoured measure of (classroom) comprehension has always been the ability to reformulate, to say the same thing differently. Curiously, of two tendencies - variation and exact repetition - humans appear more naturally inclined to the former than to the latter. It is therefore easy to understand Beaugrande's point that, in writing (e.g. popularization), it is a Herculean task "defining the technical terms clearly and using them consistently (it's harder than you'd think!)" (Beaugrande 1997:160).

There are other dimensions to indeterminacy at the level of the symbol that are not primarily related to polysemy or to homonymy as seen above. Discussions of polysemy and homonymy tie the symbol to the concept, and appear to deny that terms have a realm of existence and behaviour that is independent of the other corners of the semiotic triangle. An analysis of dissertations on terminology in the erstwhile Soviet Union shows that as early as the 1960s there already was concern with studying terms in relation to their textual boundedness (cf. Grinev 1994). Indeed, terms (as types) seem to have in the texts where they appear an additional realm of existence and behaviour in which their tokens develop relationships among themselves and with other semiotic resources, such as non-terms, grammatical patterns, text types, and so on. These relationships may in fact become indexical, leading to functional specializations. The indeterminacy here is not one of the relative inscrutability of reference, but of the intractability of the relationships (synonymy, equivalence, etc.) which tokens have developed intertextually.

Many sign models have been developed or introduced to illustrate the various strands of indeterminacy in terminology. In the appendix a few lesser known models are presented as a means of exemplifying the foregoing, and providing complementary insights. (The reader may wish to go over to the appendix at this point to fix on ideas presented thus far). 


\subsection{Implications of Theory of Indeterminacy.}

What does this all mean in light of the notorious resistance to theory of many a translation student and practitioner? (See, for instance, Chesterman \& Wagner (2002)). An upshot of the foregoing is that we are in an ère de soupçon (apologies Nathalie Sarraute) as far as the determinacy of the technical/specialist text is concerned. A corollary of this is the indispensability of text analyses in technical translation, a practice that was previously associated almost exclusively with the genre of literary translation. Like those scientists - who, suspicious of means or other central tendencies, practise analytical casuistry, relating specific instances to the gold standard, and calculating and making sense of deviations - translators of technical documents, by the foregoing theoretical account, must adopt a similar stance in relation to the text to be translated and their reference materials (technical dictionary, parallel texts, and so on).

The next section will show just how untenable a cross-linguistic slot-and-filler view of technical (or specialist) translation is. It will show the risk of taking a determinate view of lexical relations (including synonymy and equivalence) in technical translating. No less importantly, some of the modalities for text analysis of terminological indeterminacy in technical translating will be obvious.

\section{Text Analysis of Indeterminacy as Index of (Terminology) Competence in Technical Translation}

The characteristic of indeterminacy is one that pervades many language-related activities, including language teaching, intralingual communication and translating. In these days of translation as a global business, decisions on which terms to use in the target text and how to use them are therefore often seen as a matter for control, on a number of possible grounds. These include: consistency, for reasons of brand image, clarity, and, in the case of technical authorship, translatability; speed, for reasons of cost reduction; and accuracy, for reasons of safety in certain fields such as pharmaceuticals, and quality control (alongside consistency). The means by which such control is increasingly achieved are bilingual or multilingual electronically-stored terminology collections.

\subsection{Shortcomings of Dictionaries and Related Resources.}

Now, in moving repeatedly between text and terminology collection and back to text, translators are constantly engaging with the etic/emic contrast in so far as codified terminology collections are structured at the level of the lexeme, not the word form as its physical realisation in a text. Herein lie precisely the limitations of such resources. Indeed, the inclusion of fields such as linguistic information, contextual example, collocation or phraseology in fully-elaborated term bases can be regarded as one means of trying to overcome these limitations. But this is precisely the kind of data which translators are generally reluctant to provide when requested to do so by project or terminology managers, preferring instead to operate at the emic level of equivalence matching lexeme for lexeme.

When solving source-text terminology problems, translators may try to match the form and interpreted meaning of the unfamiliar lexical element with system-level representations in dictionaries, glossaries, terminologies, etc. In this approach, the usual route is to match lexeme for lexeme across languages, before shifting back to the forms and contextual meanings of the textual artefact in the form of the target text. The SL lexeme-TL lexeme matching exercise may be "offthe-shelf" from an entry in a bilingual or multilingual dictionary or terminology collection, or it may be effected through a "customised" matching of definitions in monolingual dictionaries. An alternative approach might be to use parallel text to attempt to relate mutually indeterminate phenomena.

The challenge associated with the first approach (SL word form/s-SL lexeme/TL lexeme-TL word form/s) is obvious when it is realised that linguistic and semantic relations are ever-shifting in text, and that no dictionary could hope to codify anything more than a prototype. In the parallel text approach, (SL word form/s-TL word form/s), the challenge is one of understanding relations between word forms in text, and to use this insight as basis for the kinds of decisions and judgements that the translator needs to make. 


\subsection{Terminological Indeterminacy in Technical Translation.}

The following brief extracts from two case studies reported elsewhere will help to illustrate the latter point in particular, concerning intratextual and intertextual relations.

Case Study 1: Syntagmatic relations in parallel German and English genetic engineering texts as a context for synonymy and equivalence (for further details, see Rogers 1997).

This study was undertaken using a small corpus of popular and professional-level texts in English and in German dealing with aspects of genetic engineering. The corpus, consisting of texts originally written in English and in German, was compiled as a set of parallel texts to support the translation of a genetic-engineering text from German into English ${ }^{1}$. What the study shows is that the analysis of word forms reveals probabilities-which could be regarded as a kind of indeterminacy-at the linguistic level which are lost at the lexeme level. The linguistic features investigated were morphological including number, compounding patterns and head/modifier roles in compounds. Starting from two sets of apparent synonyms, two questions were posed. How far can the synonymy of these terms be supported by textual evidence? And how can equivalence be established, given distributional variation?

The two sets of potential synonyms (and hence potential equivalents) are: disease, disorder, illness, syndrome; Krankheit, Erkrankung, Morbus, Syndrom. The lexemes DISEASE and ERKRANKUNG are the most frequent in each set, but the German term occurs more frequently in the plural than the English term. Further analysis reveals that there are distributional differences between singular and plural forms in their tendency to occur as single-word terms, e.g. disorder occurs in $50 \%$ of cases as a single-word term whereas disorders occurs in only $10 \%$ of cases. In other words, the plural form is more likely to appear as part of a compound. By contrast, illnesses always occurs as a single-word term whereas illness occurs in two thirds of cases as part of a compound. Looking further at the morphological structure of the compounds identified, it emerges that the synonyms in each language are much more likely to occur as heads of compound noun phrases than as modifiers: in English, only disease assumes this role e.g. disease strains, disease transmission. In the German data it is Krankheit which assumes this role e.g. Krankheitsempfindlichkeit, Krankheitsentstehung.

One definition of synonymy involves interchangeability. In the German compounds identified, for example, Erkrankung and Krankheit were most frequently interchanged, e.g. Infektionserkrankung, Infektionskrankheit; Grunderkrankung, Grundkrankheit. The English data showed more variation, with evidence of more flexible patterns: disease was interchanged with illness and with disorder, while disorder was also interchanged with illness e.g. human disease, human disorder; hereditary disorder, hereditary illness; genetic disease, genetic disorder; viral disease, viral illness.

A summary of the preferred-but not exclusive-functions performed by each set of synonyms begins to suggest possible equivalences. 
Table 1: Parallel functions of the selected lexemes in English and German

\begin{tabular}{|c|c|c|}
\hline environment & $\begin{array}{l}\text { preference in English } \\
\text { ( } \% \text { occurrences in plural })\end{array}$ & $\begin{array}{l}\text { preference in German } \\
(\% \text { occurrences in plural) }\end{array}$ \\
\hline $\begin{array}{l}\text { single-word term in own } \\
\text { right }\end{array}$ & $\begin{array}{l}\text { ILLNESS } \\
(83.33 \%)\end{array}$ & $\begin{array}{l}\text { ERKRANKUNG } \\
(64.29 \%)\end{array}$ \\
\hline multiword term (head) & $\begin{array}{l}\text { DISORDER (e.g. } \\
\text { HEREDITARY DISORDER) } \\
(90.00 \%)\end{array}$ & $\begin{array}{l}\text { ERKRANKUNG (e.g. } \\
\text { MONOGENE ERKRANKUNG } \\
(75.00 \%)\end{array}$ \\
\hline single-word term (head) & no occurrences & $\begin{array}{l}\text { KRANKHEIT (e.g. } \\
\text { IMMUNSCHWÄCHEKRANKHEI } \\
\text { T } \\
(85.71 \%)\end{array}$ \\
\hline multiword term (mod) & $\begin{array}{l}\text { DISEASE (e.g. DISEASE } \\
\text { TRANSMISSION }\end{array}$ & no occurrences \\
\hline single-word term (mod) & no occurrences & $\begin{array}{l}\text { KRANKHEIT (e.g. } \\
\text { KRANKHEITSENTSTEHUNG }\end{array}$ \\
\hline hyphenated term & no occurrences & $\begin{array}{l}\text { SYNDROM (e.g. } \\
\text { MIKRODELETIONS-SYNDROM } \\
(20.00 \%)\end{array}$ \\
\hline
\end{tabular}

The parallels in Table 1 suggest that, according to their role within the bounds of a term, ILLNESS and ERKRANKUNG may be in some sense regarded as equivalents (single word terms in their own right), as may also DISORDER and ERKRANKUNG (head of multiword term) and arguably DISORDER and KRANKHEIT (head of single-word compound term) since the English data has no evidence of single-word compounds ${ }^{2}$. Finally, DISEASE and KRANKHEIT could also be considered equivalent since they both function as modifiers in compounds (multiword and single-word respectively). This indicates that the one-to-one relations which normally characterise entries in bilingual dictionaries do not adequately describe the complex and probabilistic syntagmatic relations which words enter into in texts.

Case Study 2: Perspectivisation in automotive engineering texts (German and an English translation) (for further details, see Rogers 2004)

When a static view is projected on concepts in a concept system, every concept in such a system typically has a label. It does, however, happen that text-immanent dynamics throw up perspectives to concepts in a concept system, without these perspectives being codified or possessing distinct system-level or codified labels. The lack of isomorphism in mapping of concept to symbol in such situations creates a variety of indeterminacy phenomena. For instance, codified terms may be used for non-codified/difficult-to-codify perspectives. Operating with concept-term relations that are indeterminate then becomes a (conscious) problem-solving strategy.

In this second case study, an analysis of an English translation of a German automotive manual $^{3}$, we are therefore concerned with linguistic/conceptual mappings.

The referent in the two text extracts studied is an articulated vehicle, for which different types of braking systems are defined. On the basis of the original text and its English translation, the following multidimensional concept system was proposed. 
Figure 1. A multidimensional (or mixed) bilingual system for the concepts ZUGFAHRZEUG/TOWING VEHICLE and ANHÄNGEFAHRZEUG/TOWED VEHICLE based on logical and part-whole relations and including synonyms

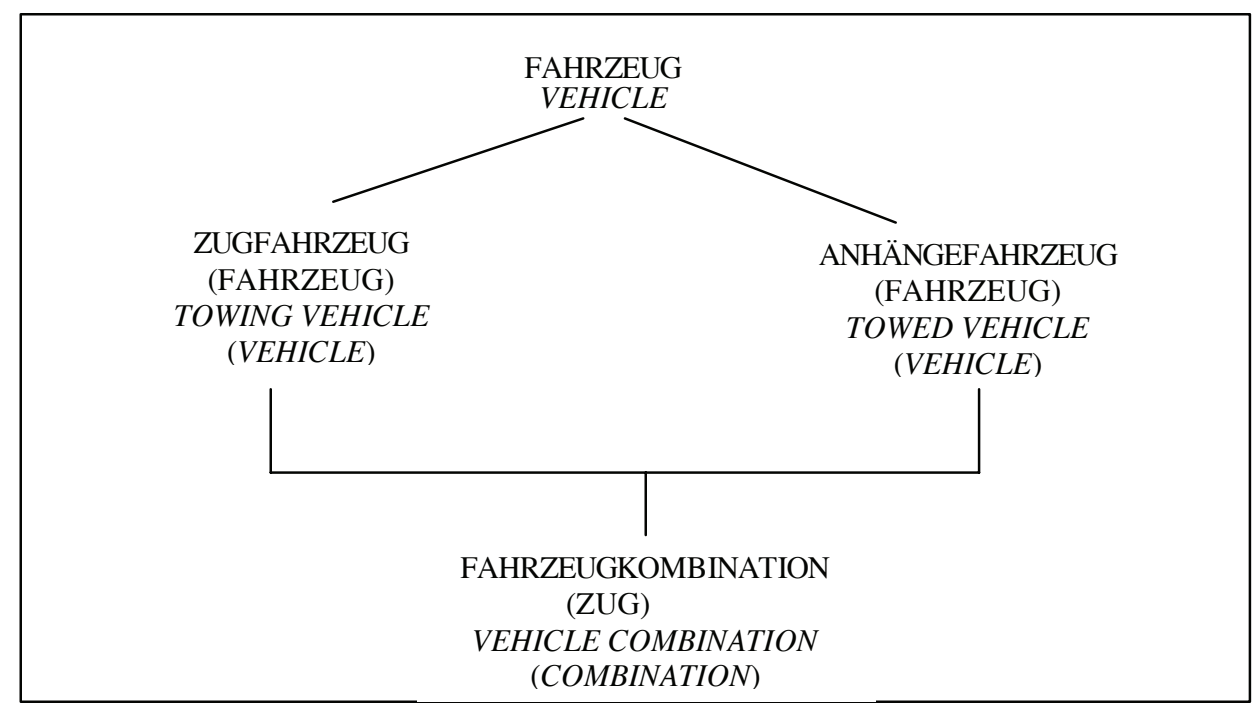

The two dimensions of the conceptual system - part-of and kind-of - are manifest in the texts through the use of different word forms and expressions to represent each case: on the one hand, to refer individually to each specific part of the whole vehicle according to its function (Zugfahrzeug; Anhängefahrzeug and towing vehicle; towed vehicle); on the other hand, to refer to the same parts but without reference to their specific respective functions (Fahrzeug and vehicle). But these can be further differentiated according to the phraseology in which each term is embedded. Hence the expressions der einzelnen Fahrzeuge and of the individual vehicles indicate an individual perspective but without any specific reference to a particular part of the overall vehicle. By contrast, the expressions der einzelnen Fahrzeuge eines Zuges and of each of the vehicles forming the combination show a collective perspective without any indication of specific parts. Our third possibility is a collective perspective for individual parts which are still not functionally differentiated: der Fahrzeuge eines Zuges and [for] vehicles forming a (vehicle) combination.

So there are, in fact, three different perspectives which can be added to the specific individual view presented by the terms Zugfahrzeug and towing vehicle, and Anhängefahrzeug and towed vehicle:

1. as an individual but non-specific part of a whole;

2. as non-specified parts of a whole viewed collectively;

3. as collective parts of the whole.

While the equivalence relationship between individual, specific concepts such as ZUGFAHRZEUG and TOWING VEHICLE is relatively predictable (ZIEHENDES FAHRZEUG is a possible synonym), the different perspectives presented in longer linguistic chunks are hard to codify from both a linguistic point of view (phraseology) and from a conceptual point of view (different views of the same object/s as collective/individual and generic/specific).

The difficulties of mapping linguistic and conceptual levels are further illustrated by a comparison of a concept system of Straßenfahrzeuge/road vehicles provided in the automotive handbook and the sketchy use of the node labels as terms in running text. Compared to the specific references to individual concepts such as Anhängefahrzeug (and synonyms) and Zugfahrzeug (and synonym), Fahrzeug/e/es/en is used more frequently. Yet in the Bosch conceptual system FAHRZEUG does not appear as a concept label; neither does VEHICLE in the English system. The relative greater frequency of the generic term Fahrzeug is due to its use as a textual synonym for more specific concepts and as a collective term for many different types of vehicle which share certain characteristics. Indeed, from a textual point of view, repeating the same compound term 
several times would be uneconomical and tedious. Generic terms, even those which do not appear to be terms in the strict sense of serving as a label for a defined concept, are functionally useful in the "textualization" of conceptual views. There is therefore in the present case no one-to-one mapping which can be consistently and transparently represented in codified form so as to ensure replication in future texts, although some terms/concepts may be more determinate than others and hence more amenable to codification or even standardization.

What these two case studies do is suggest how any definition of terminology competence in technical translation has to be based in part at least on the ability to identify and resolve a variety of indeterminacy phenomena. The case studies give the lie to a kind of cross-linguistic slot-and-filler view of technical (or specialist) translation, which presupposes a determinate view of lexical relations, including synonymy and equivalence.

\section{Handling Terminological Indeterminacy in Translation: Technologies and Methods}

Retrospectively, initial enthusiasm in developing computational tools for translating was based in part on the assumption or expectation that language use, no matter how complex, would with sustained probing turn out to be highly determinate and amenable to modelling - on which basis automation of translation would then be achieved.

Subsequent moderation of initial assumptions saw the emergence of a wide range of other tools (e.g. translation memory, ontology and taxonomy management tools), which hold the high ground in most working environments dedicated to high-quality translation and localization. However, users are quickly coming to the realization that these systems are just as efficient in reproducing poor quality translation as they are in replicating high quality products. As a consequence of these quality concerns, the evolution of computerized tools for translations comes full circle back to terminology management. If undetected, indeterminacy such as was exemplified in the preceding section leads to quality problems in terminology management. As earlier mentioned, documenting a range of term information - possibly at system, norm and parole levels is one strategy for making indeterminacy less intractable. It would also be recalled that it is precisely this information range that translators are reluctant to document when requested to by terminology project managers.

\subsection{Indeterminacy Driving Terminology Management Principles}

Efforts to manage indeterminacy and to ensure the reuse of terminological documentation have resulted in the development of basic principles specific to electronic terminology management. These include:

1) Concept orientation;

2) Term autonomy;

3) Elementarity of data elements;

4) Data element integrity;

5) Consistent mapping of data categories to a standardized set of data category definitions;

6) Documentation of terminological entries, specifically with:
a. Definitions;
b. Subject field references and scope notes;
c. Contexts;
d. Reference to reliable sources;
e. Date information.

\subsection{Illustration}

Let us illustrate a few of the above principles by looking at synonymy and homonymy, two phenomena that index indeterminacy in the concept - symbol relationship, even in technical contexts. It is well known that synonymy exists if two or more terms in a given language represent the same concept. Thus a synonym is a term used to designate the same concept as another term. To manage this kind of indeterminacy using terminology management tools, the design of the 
underlying terminological data model must follow the principle of term autonomy. Term autonomy guarantees that all terms including synonyms, abbreviated forms and spelling variants can be documented with all necessary term-related data categories. This approach can be realized by designing the data model in such a way that allows the user to create an unlimited number of term sections or term blocks containing individual terms and all additional data categories describing the term and its use. Only with this detailed documentation of all terms representing the same concept can the indeterminacy be managed. Figure 2 below shows an example of a monolingual terminological entry following the principle of term autonomy.

Figure 2: Term autonomy realized in MultiTerm ‘95 Plus

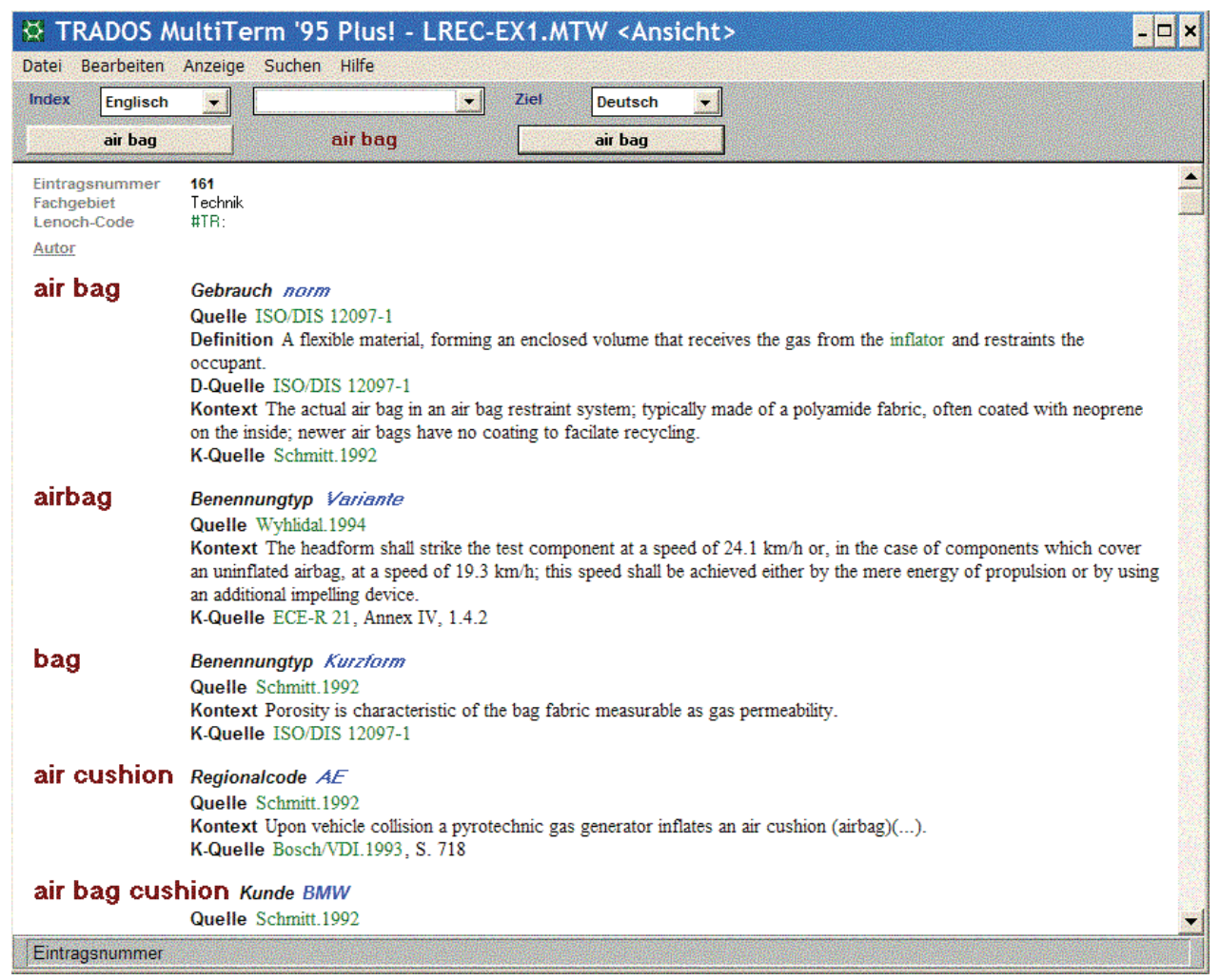

The second phenomenon in the relation between terms and concepts is called homonymy. ISO 1087-1:2000 defines homonymy as a relation between designations and concepts in a given language in which one designation represents two or more unrelated concepts. In English linguistics and grammar, what we are calling homonymy is frequently viewed either from the standpoint of polysemy (words having multiple meanings) and homonymy (concepts having "homogenized" names). Although the distinction between polysemy and homonymy is considered important in linguistics, in terminology management, however, it is not viewed as important because the two phenomena result in the same pragmatic word behavior: the same word form represents more than one concept. In term bases, we often call these duplicate terms doublettes because the same word may occur as an index two or more times in a concept-oriented term base, each time with a different meaning.

In handling homonymy using a terminology management system, the data model must follow the principle of concept orientation. Per definition, a terminological entry has to contain all terminological data related to one concept (ISO 1087-1: 2000). Therefore, the entry structure of the terminology management tool has to reflect the principle of concept orientation, thus allowing for the maintenance not only of all concept-related information but also of all terms in all languages with all term-related information within one terminological entry. Terminological entries designed 
according to the principle of term orientation, which we very often find in bilingual glossaries or dictionaries, are not appropriate for meticulous terminology management and will quickly lead to inconsistent and indeterminate terminology collections that are not very useful, especially if multilingual terminology management is required.

The foregoing does not of course preclude some form or the other of term orientation. There are sometimes challenges associated with text-immanent indeterminacy, such as when a lexeme appears to correspond, in a text corpus, to different concepts (not facets), so much so that the status of this lexeme's correlate in a system of concepts becomes doubtful; or that of morphologically different word forms of the same lexeme designating different text-immanent perspectives of the same concept. For the latter, a solution such as the one in Figure 2 is worth considering, with of course the addition of more granular context information, e.g. fields for collocation, observations, and so on. For the former, one solution in a bilingual terminology planning project was to make such lexemes (e.g. legislation in British usage) an index term, document its usage contextually and collocationally, then provide pointers (in the observation text field) to the codified concepts it designates in the reference corpus (e.g. law, bill, Act, etc). These concepts are themselves entered in the term base.

Both principles of concept orientation and term autonomy are required if terminology management is aimed to support technical translators, terminologists and documentation specialists.

\section{Conclusion}

This discussion has sought to show how research in terminology has evolved from an ancillary, even hidden, activity in translator training and in professional life to a major concern. Advances in research have had the effect of developing, making explicit and/or formalizing knowledge on terms, and this in turn has made possible the introduction of terminology curricula in translation programmes. The more clearly defined professional profile of the technical translator today owes a lot to these advances.

One sustained thrust of the knowledge that has been gained in terminology - in the variety of ways, places and periods that this has come about - is that technical communication is not as determinate as might have been believed at some point. This has been demonstrated theoretically through discussions on the relations obtaining among the tree corners of the traditional semiotic triangle, textually through bilingual text analyses, and in computerised environments through the range of design issues associated with electronic terminology management.

\section{NOTES}

1. Margaret Rogers is grateful to Iris Levy, MA student at the University of Surrey (1994-5), for providing the texts and some of the underlying questions concerning synonymy and equivalence.

2. Single-word terms may be a simple root (+affix) e.g. Krankheit or illness or a compound consisting of more than one root (+ affix/es) e.g. Krankheitsempfindlichkeit. Compounds in English tend to be multiword e.g. coronary artery disease.

3. AdLER, U. (ed.) 1984: Kraftfahrzeugtechnisches Taschenbuch 19, Stuttgart, Robert Bosch GmbH and ADLER, U. (ed.) 1986: Automotive Handbook, $2^{\text {nd }}$ ed., Stuttgart, Robert Bosch GmbH (Translation by Ingenieurbüro für Technische und Naturwissenschaftliche Übersetzungen Dr. W.-D. Haehl GmbH, Stuttgart, Edward L. Crosby III).

\section{RÉFÉRENCES}

AnTIA, B.E. (2001): "Metadiscourse in terminology: thesis, antithesis, synthesis", Terminology Science \& Research $12(1-2)$, p. 65-84.

AnTiA, B.E. (2002): "II termine: contesto definitorio e contesto d'uso", in MAGRIS, M., M. T. MuSACCHIO, L. REGA e F. SCARPA (eds.): Manuale di terminologia. Aspetti teorici, metodologici e applicativi, Milan, Hoepli, p. 99-114. 
ARntz, R., H. PICHT und F. MAYER (2002): Einführung in die Terminologiearbeit, Hildesheim, Olms.

Averbuh, K. JA. (1994): „E. K. Drezen, Terminologist and Standardiser“, Terminology Science \& Research 5-2, p. 5373.

BEAUGRANDE, R. (1987): "Determinacy distributions in complex systems: science, linguistics, language, life“, Zeitschrift für Phonetik, Sprachwissenschaft und Kommunikationsforschung 40, p. 145-188.

BeAugrande, R. (1997): New Foundations for a Science of Text and Discourse: Cognition, Communication and the Freedom of Access to Knowledge and Society, Norwood, Ablex.

Budin, G. (1994): “Do we need an object theory?” in DRASKAU, J. K. and H. PICHT (eds.): Terminology Science \& Terminology Planning/Theoretical Issues of Terminology Science, Vienna, TermNet, p. 203-208.

Budin, G. (2001): “A Critical Evaluation of the State-of-the-Art of Terminology Theory”, Terminology Science \& Research 12 (1-2), p. 7-23.

Chesterman, A. and E. Wagner (2002): Can Theory Help Translators? A Dialogue Between the Ivory Tower and the Wordface, Manchester, St. Jerome.

Felber, H. und G. Budin (1989): Terminologie in Theorie und in Praxis, Tübingen, Günter Narr.

GERZYMisCH-ARBOGAST, H. (1996): Termini im Kontext. Verfahren zur Erschließung und Übersetzung von der textspezifischen Bedeutung von fachlichen Ausdrücken, Tübingen, Günter Narr.

Hunter, K. M. (1991): Doctors'stories, Princeton, Princeton University Press.

Holmes, J. (1972): “The name and nature of translation studies", Unpublished ms reprinted in TouRY, G. (ed.): (1987) Translation Across Cultures, New Delhi, Bahri Publications.

ISO 1087-1 (2000): Terminology work - Vocabulary - Part 1: Theory and application, Geneva, ISO.

ISO 12200 (1999): Computer applications in terminology - Machine-readable terminology interchange format (MARTIF) - Negotiated Interchange, Geneva, ISO.

ISO 12620 (1999): Computer applications in terminology - Data categories, Geneva, ISO.

ISO 16642 (2003): Computer applications in terminology - Terminological markup framework, Geneva, ISO.

LAurÉn, C., J. MyKing und H. PICHT (1998): Terminologie unter der Lupe. Vom Grenzgebiet zum

Wissenschaftszweig, mit Beiträgen von Anita Nuopponen und Nina Pilke, Vienna, TermNet.

LEMKE, J. L. (1990): Talking Science, Connecticut/London, Ablex.

Picht, H. (1993): "State-of-the-art of Terminology Training in 1991”, Terminology Science \& Research 4, p. 2-33. PICHT, H. (1997): „Wirtschaftslinguistik: ein historischer Überblick“, in HOFFMANN, L., H. KALVERKÄMPER und H. E.WIEGAND (eds.): Fachsprachen. Languages for Special Purposes. Ein Internationales Handbuch zur Fachsprachenforschung und Terminologiewissenschaft, Berlin, New York, Walter de Gruyter, p. 336-341. RAT FÜR DEUTSCHSPRACHIGE TERMINOLOGIE (2004): Berufsprofil. Terminologin. Terminologe, Bern. RigGS, F. (1987): “Social science vocabulary: the INTERCOCTA project”, TermNet News 18, p. 7-15. RoGERS, M. (1997): "Synonymy and equivalence in special-language texts. A case study in German and English texts on Genetic Engineering”, in TrosborG, A. (ed.): Text Typology and Translation, Amsterdam/Philadelphia, John Benjamins, p. 217-45.

Rogers, M. (2004): "Multidimensionality in Concept Systems: A Bilingual Textual Perspective", Terminology 102, p. 215-40.

SCHMITZ, K.-D. (2001): “Criteria for evaluating terminology database management programs”, in WRIGHT, S. E. and G. Budin (eds.): Handbook of terminology management II, Amsterdam/Philadelphia, John Benjamins, p. 539551.

SchMiTZ, K.-D. (2005): “Terminology and Terminological Databases”, in BROWN, K. (ed.): Encyclopedia of Language and Linguistics, 2nd Edition, Oxford, Elsevier Publishers.

Wright, S. E. (2003): "From the semiotic triangle to the semantic web", Terminology Science \& Research 14, p. 111-135.

Wright, S. E. and G. BUDIN (eds.) (1997): Handbook of terminology management I, Amsterdam/Philadelphia, John Benjamins.

Wright, S. E. and G. BUdIN (eds.) (2001): Handbook of terminology management II, Amsterdam/Philadelphia, John Benjamins.

WÜSTER, E. (1959): „Das Worten der Welt, schaubildlich und terminologisch dargestellt“, in PICHT, H. und K.-D. SCHMITZ (eds.): Terminologie und Wissensordnung, Cologne, TermNet (2001), p. 21-51.

WÜSTER, E. (1979): Einführung in die Allgemeine Terminologielehre und Terminologische Lexikographie, Vienna/New York, Springer. 


\section{APPENDIX}

Figure 3: Gerzymisch-Arbogast (a), simplified

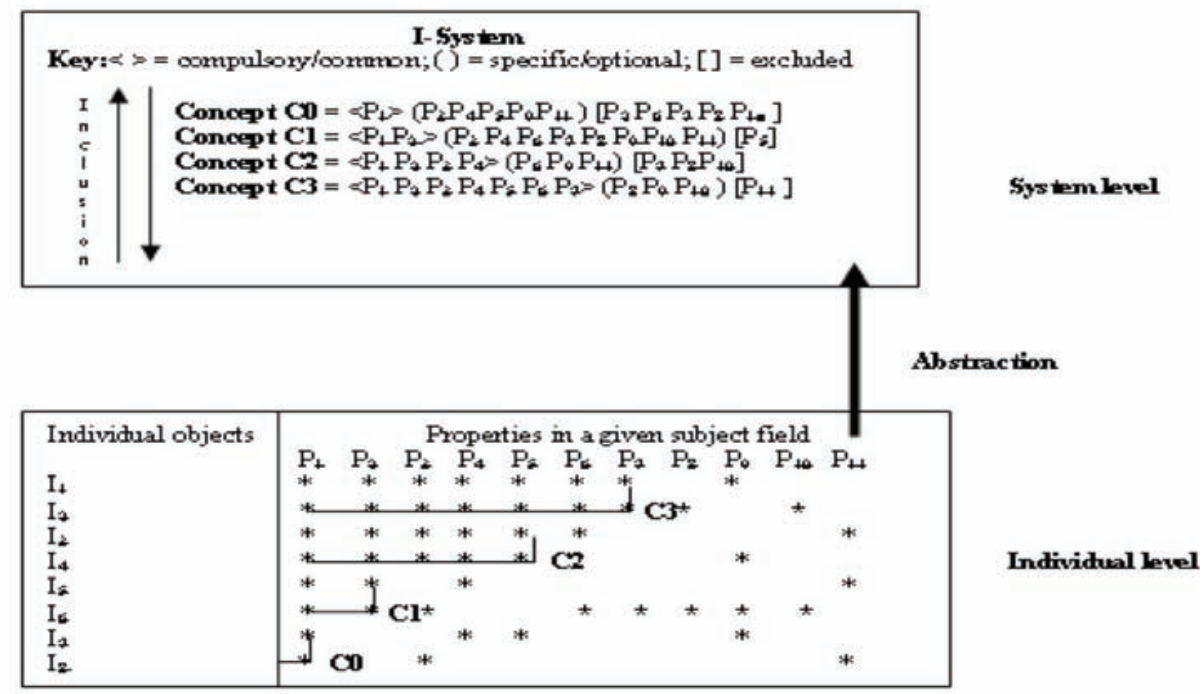

Even where specialist concepts $(\mathrm{CO}-\mathrm{C} 3)$ are formed by abstracting from the properties of individual objects in reality $\left(\mathrm{P}_{1}-\mathrm{P}_{11}\right)$, these concepts exist for us not as a set of invariant characteristics only, but rather as a conjunction of three categories of characteristics: compulsory/generic; optional or specific to certain kinds; excluded. A basis is thus provided for a variety of sense relation types: hyperonymy, hyponymy, unrelatedness, etc. 
Conoepts $(\infty \ldots)$ are given designations $\left(\mathrm{d}_{\mathrm{b}} . ..\right)$ based, for inst ance, on convertions in a discipline

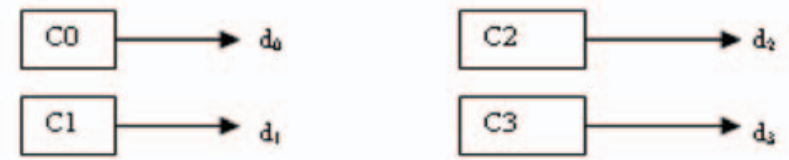

Systemlevel

Contextualization of type to then

Token designations

$d_{0}-d_{1}-d_{2}-d_{1}-d_{3}-d_{2}-d_{0}-d_{4}$

Relation of token designations to token concepts

$d_{1} \rightarrow \mathrm{Cl}$

(ideal relation)

$\mathrm{d}_{2} \longrightarrow \mathrm{C} 2$

$d_{1}$

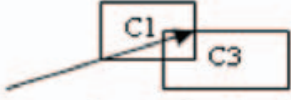

(cont aminated relation)
Individual

level, eg an LSP text

(contaminated relation)

When used in text, terms (as constructs uniting concepts and conventionally assigned designations) may exemplify an ideal type-token relation (in which case contextualization has had no impact on the system level acceptation). More commonly, though, contamination occurs, sometimes as a realization of the potential for hyponymic or hyperonymic shifts evident in concepts being a conjunction of three categories of characteristics.

Figure 5: Symbolic \& Indexical Relationships in Cognitive Linguistics (Deacon, Pierce)

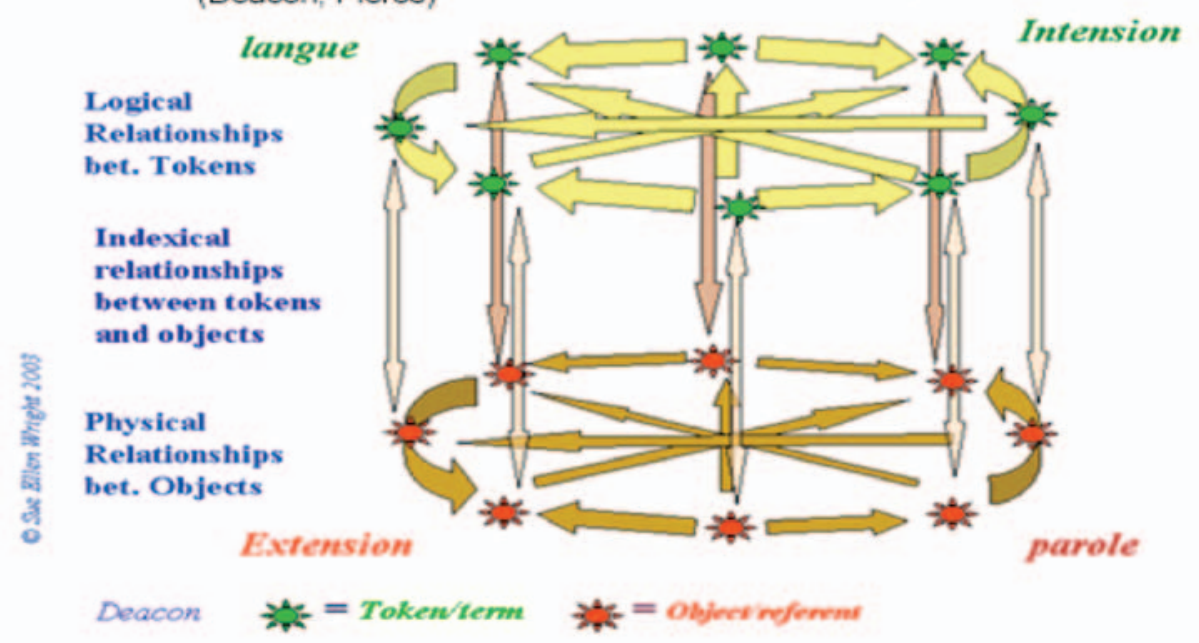

The drect relationship which Saussure entertains between signifier and signified is in light of Deacon's acoount rather simple because it fails to take into acoount the set of horizontal relationships into which both objects and tokens subordinated. Because the enty points will repeatedly differ, there can be no expectation of immutability in the link 


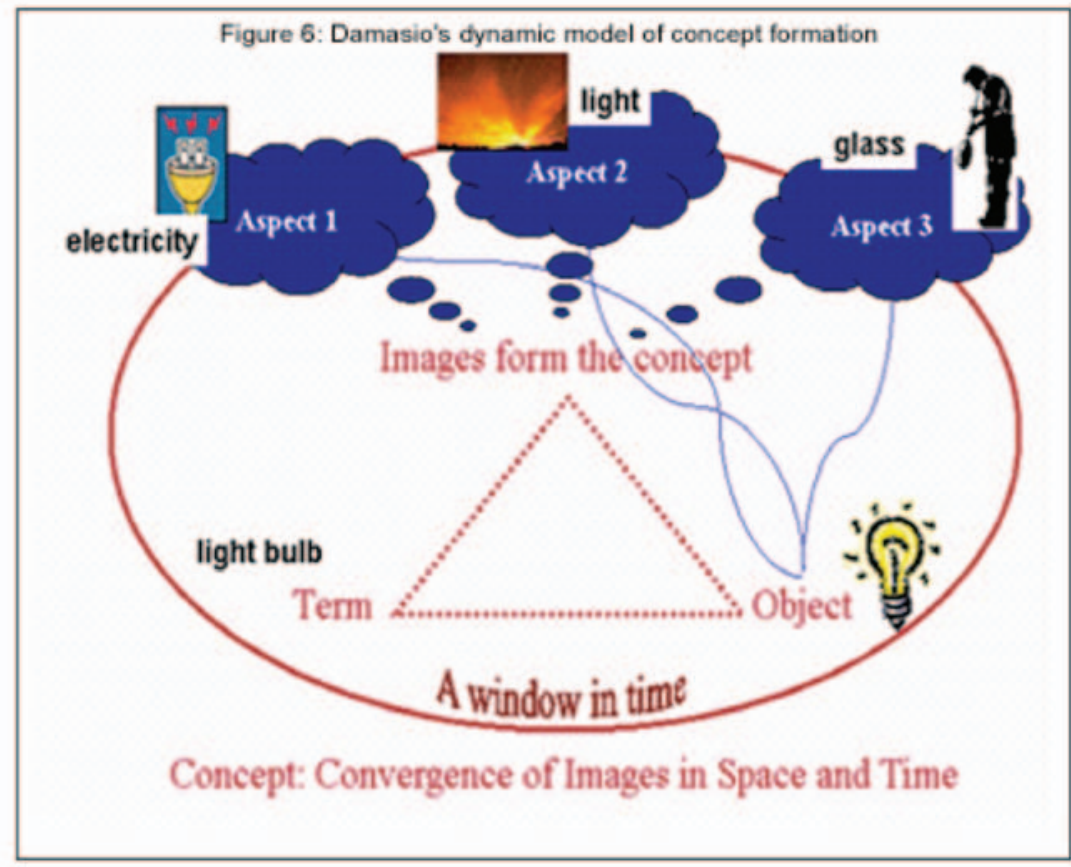

A concept has as its basis a set of potental and fleetng images, which will converge in different configurations within difterent spato-temporal windows. A concept is therefore not already there, prefabricated and stable. Reference is a process of aggregating images or charactenstics and is therefore potentially very dynamic. 